\title{
The Effectiveness of Zoom Meeting Application and Comedy Film Media on Students' Anecdot Writing Ability
}

\author{
Ade Siti Haryanti*), \\ Universitas Sultan Ageng Tirtayasa \\ Achmad Hufad, \\ Universitas Pendidikan Indonesia \\ Maman Fathurrohman, \\ Universitas Sultan Ageng Tirtayasa \\ *) Correspondences author: Jalan Raya Jakarta KM. 4 Pakupatan Serang Banten; Indonesia \\ e-mail:7782210002@untirta.ac.id
}

\begin{abstract}
The purpose of this research: (1) to know the effectiveness of zoom meeting application on the ability to write anecdotes. (2) to know the influence of comedy film media on the ability to write anecdotes. (3) to know the influence if the interaction of zoom meeting application and comedy film media together on the ability to write anecdotes. The research is a quantitative with the type used is experimental study using a $2 \times 2$ factorial design. This design used to examine two independent variables (zoom meeting application and Comedy Film Media) against one dependent variable (writing anecdotes) with the help of SPSS version 16 for windows application. The sample of the research as many as 40 students and take a sample random technique. Data collection was done by means of a student's writing ability test. The findings of the researcher indicate that: (1) there is a significant influence of students using the zoom meeting application on the ability to write anecdotes, with the acquisition value $F_{0}=5,415$ and sig. $=0,026 \leq 0,05 ;$ (2) there is a significant of students using the comedy film media on the ability to write anecdotes, with the acquisition value 11.094 and sig. $=0,02 \leq 0,05$; (3) there is no significant effect of the zoom meeting application and comedy film media on students' anecdotes writing skills, with the acquisition value $\mathrm{F}_{0}=1.518$ and sig. $=0,226 \geq 0,05$.
\end{abstract}

Keywords: Zoom Meeting Aplication, Comedy Film, Writing Ability.

\begin{abstract}
Article History: Received: 21/09/2021; Revised: 04/12/2021; Accepted: 04/12/2021; Published: 30/12/2021
How to Cite (MLA $7^{\text {th }}$ ): Haryanti, Ade Siti, Achmad Hufad, and Maman Fathurrohman. “The Effectiveness of Zoom Meeting Application and Comedy Film Media on Students' Anecdot Writing Ability." Hortatori Jurnal Pendidikan Bahasa dan Sastra Indonesia 5.2 (2021): 86-96. Print/Online. Copyrights Holder: Ade Siti Haryanti, Achmad Hufad, Maman Fathurrohman. First Publication: Hortatori Jurnal Pendidikan Bahasa dan Sastra Indonesia (2017).
\end{abstract}

\section{Pendahuluan}

Era Pandemik Covid 19 ini membawa banyak dampak perubahan bagi dunia pendidikan. Pendidikan harus terus berjalan sekalipun pandemik ini belum berakhir. Ini merupakan tugas kita bersama untuk tetap berusaha agar peseta didik tidak kehilangan hak nya untuk belajar. Dalam hal ini bukan hanya tugas guru atau dosen untuk menunjang keberhasilan belajar mahasiswa, namun ini tugas kita bersama antar dosen dan orang tua mahasiswa harus memantau anaknya dalam melaksanakan kegiatan perkuliahan, agar tujuan utama atau capaian yang diharapkan dapat berhasil sesuai dengan apa yang diharapkan, maka dari itu mahasiswa harus aktif dan kreatif sekalipun dihadapi dengan kondisi dunia yang sedang tidak baik.

Perkembangan ilmu pengetahuan dan teknologi informasi sangat berkembang pesat dari waktu ke waktu sehingga sistem pendidikan pun harus mengikuti dengan perkembangan zaman. Ilmu pengetahuan 
dan teknologi ini merupakan dua hal yang tidak dapat dipisahkan satu dengan lainnya, keduanya harus berjalan beriringan untuk melahirkan para penerus bangsa yang berkompeten. Namun dalam hal ini akan mengubah segalanya, terlebih lagi pada saat Indonesia dilanda dengan hadirnya pandemik yang sudah berjalan selama hampir dua tahun. Kita dihadapi dengan sesuatu yang baru, baik cara berpikir hingga cara berinteraksi dengan masyarakat lainnya.

Berdasarkan hal itu maka pelaksanaan pendidikan dilakukan secara daring yang kita kenal elearning atau electronic learning adalah merupakan proses penyampaian pengetahuan dalam proses belajar mengajar dengan mengaplikasikan perkembangan teknologi (Dewi, 2019). E-learning menurut (Yunita, 2021)) merupakan suatu proses pembelajaran yang berbasis elektronik yang memungkinkan untuk dikembangkan dalam bentuk berbasis website. Sistem E-Learning yang tidak memiliki batasan akses inilah yang memungkinkan perkuliahan bisa dilakukan tanpa waktu yang terbatas, kapan pun mahasiswa bisa mengakses dengan sistem ini, terdapat penyampaian bentuk teks selain itu juga ada forum diskusi, dan seorang Dosen juga mampu memberikan nilai, tugas dan pengumuman kepada mahasiswa (Aurora, 2019). Dengan demikian dapat disimpulkan bahwa elearning merupakan proses pembelajaran dengan menggunakan alat bantu aplikasi dalam pelaksanaannya. Dan tentunya diharapkan pembelajaran elearning ini dapat berjalan dengan baik.

Pada saat kita melaksanakan pembelajaran secara daring tentunya membutuhkan media sebagai sarana pembelajaran. Ada berbagai Platform yang dapat digunakan sebagai media pembelajaran oleh Universitas diantaranya Google Classroom, Zoom Meeting, Whatsapp, Google Meet, dan sebagainya. Dalam hal ini Platform yang banyak dipergunakan adalah aplikasi Zoom Meeting dan Google Classroom. Menurut (Haqien, 2020) zoom meeting merupakan sebuah media pembelajaran menggunakan video. Dalam aplikasi Zoom Meeting ini kita bisa berkomunikasi langsung dengan siapa pun lewat video. Oleh karena itu, memang cocok digunakan sebagai media pembelajaran. Zoom Meeting merupakan layanan konferensi video yang mempunyai kemampuan efisien dan juga fleksibel dalam menghadirkan suasana meeting secara daring (Irmada, 2021). Dengan demikian dapat disimpulkan bahwa penggunaan aplikasi zoom meeting sangat mudah dipergunakan dalam kegiatan pembelajaran karena lebih fleksibel dan komunikatif, dengan menggunakan aplikasi zoom meeting ini kita dapat berkomunikasi antara mahasiswa dengan Dosen secara langsung.

Google classroom dirancang untuk mempermudah interaksi guru dan siswa dalam dunia maya. Aplikasi ini memberikan kesempatan kepada guru untuk mengeksplorasi gagasan keilmuan yang dimilikinya kepada siswanya (Mulatsih, 2020). Melalui aplikasi Google Classroom diasumsikan bahwa tujuan pembelajaran akan lebih mudah direalisasikan dan sarat kebermaknaan. Menurut (Bunyamin, 2019) Google Classroom merupakan sebuah aplikasi berbasis internet yang dibuat oleh Google sebagai sebuah sistem E-learning yang memungkinkan terciptanya ruang kelas di dunia maya. Selain itu, Google Classroom bisa menjadi sarana penyampaian teori pembelajaran, diskusi antara sesama siswa ataupun guru bidang studi, distribusi tugas atau ujian bahkan menilai tugas-tugas yang dikumpulkan siswa. Dengan penggunaan aplikasi Google Calssroom guru ataupun dosen diberikan kesempatan untuk memberikan materi pelajaran melalui aplikasi ini dengan mengirimkan materi pembelajaran ataupun tugas-tugas latihan yang tentunya sangat bermanfaat bagi mahasiswa.

Menurut (Sukiman. 2012) media pembelajaran adalah segala sesuatu yang dapat digunakan untuk menyalurkan pesan dari pengirim ke penerima sehingga merangsang pikiran, perasaan, perhatian dan minat serta kemauan peserta didik sedemikian rupa sehingga proses belajar terjadi dalam rangka mencapai tujuan pembelajaran secara efektif. Media pembelajaran dijadikan motivasi agar menumbuhkan minat belajar mahasiswa, kerana media pembelajaran diharapkan menjadikan alat agar proses belajar-mengajar berjalan dengan baik. Menurut (Miftah. 2013) media adalah suatu alat atau sarana atau perangkat yang berfungsi sebagai perantara atau saluran atau jembatan dalam kegiatan komunikasi (penyampaian dan penerimaan pesan) antara komunikator (penyampai pesan) dan komunikan (penerima pesan). Dengan menggunakan media pembelajaran diharapkan agar materi yang ingin disampaikan dapat tersampaikan dengan baik melalui media sebagai perantaranya. Berdasarkan pendapat para ahli di atas maka dapat disimpulkan bahwa media pembelajaran merupakan alat atau strategi yang baik dipergunakan guna menumbuhkan motivasi belajar bagi peserta didik, dengan begitu tujuan atau target yang ingin dicapai dapat mudah dipahami, karena sesuatu yang tidak bisa tersampaikan oleh guru dapat digantikan dengan media sebagai perantaranya.

Begitu banyak media yang dapat dipergunakan dalam pembelajaran, Media pembelajaran sendiri harus disesuaikan dengan kondisi dan situasi. Maka dari itu berdasarkan hasil penelaahan dapat dikatakan 
bahwa media film sangat baik dipergunakan untuk memotivasi mahasiswa dalam mengikuti kegiatan belajar mengajar. Menurut (Sukiman, 2012) Film adalah gambar-hidup, juga sering disebut movie. Film, secara kolektif, sering disebut sinema. Sinema itu sendiri bersumber dari kata kinematik atau gerak. Film merupakan jenis media yang memanfaatkan audio-visual. Media audio visual menghasilkan suatu gambar dan suara. Karakteristik media ini ditunjang dengan gambaran kehidupan yang lebih nyata dan atraktif.

Menurut (Ramli, 2012) menjelaskan kelebihan dan kekurangan media audio-visual kelebihan: a) Dengan menggunakan video (disertai suara atau tidak), kita dapat menunjukkan kembali gerakan tertentu. b) Dengan video, penampilan siswa dapat segera dilihat kembali untuk dikritik atau dievaluasi. c) Dengan menggunakan efek tertentu dapat diperkokoh baik proses belajar maupun nilai hiburan dari penyajian itu. d) Anda akan mendapatkan isi dan susunan yang utuh dari materi pelajaran/latihan, yang dapat digunakan secara interaktif dengan buku kerja, buku petunjuk, buku teks, alat atau benda lain yang biasanya untuk di lapangan. e) informasi yang dapat disajikan secara serentak pada waktu yang sama di lokasi (kelas) yang berbeda, dan dengan jumlah penonton atau peserta yang tak terbatas, dengan jalan menempatkan monitor (pesawat televisi) di kelas-kelas. f) Suatu kegiatan belajar mandiri di mana siswa belajar sesuai dengan kecepatan masing-masing dapat dirancang.

Kelemahan: a) Ketika akan digunakan, peralatan video tentu harus sudah tersedia di tempat penggunaan; dan harus cocok ukuran dan formatnya dengan pica video yang akan digunakan. b) Menyusun naskah atau skenario video bukanlah pekerjaan yang mudah dan menyita waktu. c) Biaya produksi video sangat tinggi dan hanya sedikit orang yang mampu mengerjakannya. d) Apabila gambar pada pica video ditransfer ke film hasilnya jelek. e) Layar monitor yang kecil akan membatasi jumlah penonton, kecuali jaringan monitor dan sistem proyeksi video diperbanyak. f) Jumlah huruf pada grafis untuk video terbatas, yakni separuh dari jumlah huruf grafis untuk film/gambar di-am. g) Bila Anda menggunakan grafis yang berwarna pada TV hitam putih haruslah berhati-hati sekali. Contoh: warna-warna merah dan hijau dengan kepekatan tertentu akan terlihat sama pada layar TV hitam putih. Sedapat mungkin usahakan membuat grafis dengan warna hitam-putih atau kelompok abu-abu. h) Perubahan yang pesat dalam teknologi menyebabkan keterbatasan sistem video menjadi masalah yang berkelanjutan.

Begitu banyak film yang dapat dijadikan media pembelajaran, dalam hal ini penulis menggunakan media film bergenre komedi. Film komedi diharapkan mampu menumbuhkan ide dalam sebuah tulisan. Film komedi juga memiliki plot yang riang dan sengaja dirancang untuk menghibur serta mengundang tawa dengan melebih-lebihkan situasi, bahasa, tindakan, hubungan, dan karakter. Menurut Berger dalam (Afifuloh, 2019). Salah satu film yang dapat dipergunakan untuk mempresentasikan potensi secara apik adalah film pendek yang berjudul "TELAT (Budaya Indonesia)" Hope Production oleh SMK 2 Cikarang Barat tahun 2013. Film pendek ini diharapkan dapat menjadi media yang menumbuhkan imajinasi bagi penikmatnya, dengan begitu mahasiswa akan dapat mudah menuliskan teks anekdot secara baik dan benar.

Ada beberapa jenis keterampilan berbahasa yang harus dipahami, salah satunya adalah keterampilan menulis, keterampilan menulis merupakan sebuah keterampilan berbahasa yang sangat berhubungan dengan keterampilan lainnya, karena menulis merupakan sebuah kegiatan produktif yang dapat menguras pikiran, waktu, dan tenaga sehingga sangat membutuhkan media dan metode pembelajaran yang tepat agar terciptanya kondisi pembelajaran yang kondusif. Keterampilan menulis dalam pemerolehannya dan pemakaiannya dianggap sebagai keterampilan yang sangat sukar dan sulit serta kompleks, menurut Akhadiah dalam (Haryanti, 2018). Menulis merupakan suatu keterampilan yang dianggap sulit oleh peserta didik, terkadang peserta didik sulit sekali mengungkapkan ide atau pikiran dalam bentuk tulisan, maka dari itu seorang penulis yang baik merupakan seorang pembaca yang baik, begitu sebaliknya sorang pembaca yang baik merupakan seorang penulis yang baik. Dalam hal ini ada hubungan yang sangat erat antara membaca (reseptif) dan menulis (produktif).

Menulis merupakan kegiatan menyampaikan gagasan, pesan, informasi, atau perasaan secara tertulis kepada pembaca atau pihak lain (Rahman, Fauzi, 2020)dengan kegiatan menulis maka kita mampu untuk mengungkapkan apa yang kita pikirkan dan rasakan sehingga menghasilkan pesan yang ingin disampaikan oleh seorang penulis kepada seorang pembaca. Menurut (Septiani, 2017) menulis atau mengarang mengungkapkan pikiran, ide, dan perasaan melalui lambang grafis, atau simbol yang sistematis. Dengan demikian kegiatan menulis merupakan kegiatan yang sangat kompleks karena menulis menuntut seseorang agar mampu menuangkan ide dan perasaan ke dalam lambang-lambang tulisan.

Seperti yang kita ketahui bahwa ada beberapa jenis keterampilan menulis, salah satunya adalah teks anekdot. Teks anekdot adalah cerita singkat yang di dalamnya mengandung unsur lelucon, menarik, dan mengesankan. cerita singkat yang menarik karena lucu dan mengesankan, biasanya mengenai orang 
penting atau terkenal dan berdasarkan kejadian yang sebenarnya (Rifai, 2019). Teks anekdot merupakan jenis tulisan yang menulis suatu kritik tertentu namun disuguhkan dengan bahasa sederhana di dalamnya ada unsur humor, teks anekdot ini berisi teks faktual. Tujuan dari suatu teks anekdot adalah untuk menghibur dengan membangkitkan tawa pembaca, hingga mengkritik. Menurut (Rifai, 2019) Teks anekdot memiliki unsur struktur yaitu: (a) Abstraksi adalah Teks anekdot diawali dengan abstrak yang berisi uraian ringkas tentang objek atau hal yang hendak disindir atau dikritik. (b) Orientasi adalah cerita dilanjutkan dengan pengenalan terhadap pelaku dan peristiwa. (c) Krisis adalah Memuat tahapan peristiwa dan cerita mulai memuncak dan hampir menuju ke penyelesaian. (d) Reaksi adalah Jawaban terhadap permasalahan yang diajukan pada tahap krisis. Ini merupakan inti kritik yang memuat unsur lucu atau. Struktur Teks Anekdot mengesankan. (e) Koda adalah Berisi penutup, yang merupakan penegasan terhadap hal yang dikritik atau disindir.

Kemampuan menulis merupakan kemampuan yang harus dimiliki oleh seorang mahasiswa agar mampu mengungkapkan ide pokok dan gagasan utama yang dimilikinya, penelitian relevan yang pertama yang ditulis oleh (Haqien, 2020)yang berjudul "Pemanfaatan Zoom Meeting untuk Proses Pembelajaran Pada Masa Pandemik Covid-19" hasil dari penelitian tersebut menunjukkan bahwa penggunaan aplikasi Zoom Meeting tidak begitu efektif bagi para mahasiswa Universitas di Jakarta dan Depok. Tetapi, aplikasi Zoom Meeting lebih baik karena dalam aplikasi Zoom Meeting komunikasi antara individu dilakukan secara lisan dibandingkan penggunaan aplikasi pembelajaran yang melakukan kegiatan komunikasi secara tertulis menurut teori komunikasi pendidikan. Penelitian relevan yang kedua ditulis oleh (Asrori, 2021) dengan judul" Pemanfaatan Google Classroom dalam Pembelajaran Menulis Puisi Masa Pandemik Covid19 "Hasil penelitian menunjukkan bahwa proses pembelajaran menulis puisi masa pandemik. Pemanfaatan Google classroom dalam pembelajaran menulis puisi pada masa pandemik Covid-19 di SMA Negeri 1 Sine dianggap tepat sebagai salah satu media dalam pembelajaran. Sebanyak $60,3 \%$ siswa menjawab tertarik belajar puisi dengan "Google classroom" dan "Google classroom" memberikan pengalaman baru.

Penelitian-penelitian terdahulu yang disebutkan di atas tentunya relevan dengan penelitian ini. Akan tetapi, penelitian ini dikhususkan pada keterampilan menulis anekdot mahasiswa Universitas Indraprasta PGRI melalui Aplikasi Zoom Meeting dengan media film komedi. Pembelajaran melalui Aplikasi Zoom Meeting ini diharapkan dapat berjalan dengan lancar dan efisien dalam masa pandemik covid 19, tentunya dengan menggunakan aplikasi dan media pembelajaran yang tepat dengan begitu tujuan yang diharapkan dalam setiap pembelajaran dapat terselesaikan dengan baik. Penerapan Aplikasi Zoom Meeting dengan memanfaatkan media film komedi diharapkan dapat meningkatkan hasil belajar menulis anekdot mahasiswa.

Berdasarkan masalah di atas penelitian ini bertujuan (1) untuk mengetahui efektifitas aplikasi zoom meeting terhadap kemampuan menulis anekdot. (2) untuk mengetahui pengaruh media film komedi terhadap kemampuan menulis anekdot. (3) untuk mengetahui pengaruh interaksi aplikasi zoom meeting dan media film komedi secara bersama-sama terhadap kemampuan menulis anekdot.

\section{Metode}

Penelitian ini merupakan penelitian kuantitatif dengan jenis penelitian eksperimen. Desain penelitian yang digunakan adalah eksperimen semu (quasi eksperimen). Menurut Nasir dalam (Haryanti, 2016) eksperimen adalah penelitian yang dilakukan dengan mengadakan manipulasi terhadap objek penelitian serta adanya kontrol. Penelitian ini dilaksanakan dengan memberikan perlakuan terhadap kelompok eksperimen. Kelas yang diberi perlakuan dengan menggunakan aplikasi zoom meeting (eksperimen) dan kelas yang diberi perlakukan dengan google classroom (kontrol). Penelitian ini menggunakan rancangan factorial (factorial design) 2x2. Dengan bantuan aplikasi SPSS versi 16 for windows.

\section{Tempat dan Waktu penelitian}

Penelitian ini dilakukan di Universitas Indraprasta PGRI beralamat di Jalan Raya Tengah No. 80 Kelurahan Gedong, Kecamatan Pasar Rebo Jakarta Timur. Pelaksanaan penelitian ini pada semester Gasal 2020. Persiapan penelitian ini dimulai dari September 2020 dan diakhiri bulan Januari Penelitian ini dilakukan kurang lebih selama 5 bulan.

\section{Populasi dan Sampel}


Populasi dari penelitian ini adalah seluruh mahasiswa semester 3 pada mata kuliah menulis. Jumlah kelas adalah sebelas kelas secara keseluruhan terdiri atas 384 mahasiswa. Sampel ialah bagian dari populasi yang ditentukan dan ditetapkan dengan menggunakan rumus-rumus tertentu, Margono dalam (Defrizal, 2020). Dalam penelitian ini sampel diambil secara acak. Sampel dilakukan secara homogen yaitu mengambil secara acak 2 kelas yang berjumlah 73 mahasiswa dengan menggunakan metode acak random. Dari hasil perhitungan rumus Slovin dengan error tolerance diperoleh ukuran sampel penelitian sebanyak 40 mahasiswa. Menurut (Sugiyono), sample random sampling dikatakan simple (sederhana) karena mengambil anggota sampel dari populasi dilakukan secara acak tanpa memperhatikan strata yang ada dalam populasi. Peneliti mengambil dari kelas R3A dengan jumlah mahasiswa 20 (eksperimen), dan R3D dengan jumlah mahasiswa 20 (kontrol), masing-masing sampel telah mewakili dua kelas tersebut sesuai dengan mutu dari mahasiswa.

\section{Teknik Pengumpulan Data}

Teknik pengumpulan data yang digunakan dalam penelitian in adalah tes tertulis.

Dalam penelitian ini, tes yang dipergunakan adalah tes kemampuan menulis mahasiswa dengan menggunakan aplikasi zoom meeting. Mahasiswa disuruh untuk melihat film komedi, kemudian menuliskan kembali menjadi sebuah tulisan anekdot. Tes ini bertujuan untuk mengukur kemampuan menulis. Teknik ini bertujuan untuk membandingkan hasil penelitian pada kelas eksperimen dan kelas kontrol. Dengan tes ini terlihat apakah aplikasi zoom meeting dan pemanfaatan media film komedi memberikan pengaruh kepada kemampuan menulis mahasiswa.

Tes dilakukan sebanyak dua kali, di awal dan di akhir pada kedua kelas baik kelas eksperimen maupun kelas kontrol. Tes awal dilakukan untuk mengetahui kemampuan menulis mahasiswa di kedua kelas tersebut. tes akhir setelah kelas eksperimen mendapat perlakuan dengan media film komedi dan kelas kontrol dengan menggunakan media konvensional (modul menulis). Tes akhir ini bertujuan untuk mengetahui perbandingan mahasiswa dua kelas tersebut. maksudnya sebelum dilaksanakan tes akhir, dilakukan proses pengajaran dengan aplikasi zoom meeting dengan memanfaatkan media film komedi pada kelas eksperimen. Selanjutnya, kegiatan pengajaran menulis dengan menggunakan metode Google Classroom dengan media pembelajaran konvensional (modul menulis) pada kelas kontrol.

\section{Hasil dan Diskusi}

\section{Deskripsi Data Penelitian}

1. Deskripsi kemampuan menulis anekdot dengan perlakuan menggunakan aplikasi zoom meeting dengan memanfaatkan media film komedi. (A1B1)

Deskripsi kemampuan menulis anekdot dengan perlakuan menggunakan aplikasi zoom meeting dengan memanfaatkan media film komedi. Secara keseluruhan memiliki rentang 80 - 90 dengan skor terendah 80 dan skor tertinggi 90 dengan mempunyai nilai rata-rata 83 , nilai median 82,5 nilai modus 80, dan standar deviasi 4,116.

Berikut ini distribusi frekuensi dan histogram kemampuan menulis anekdot dengan perlakuan menggunakan aplikasi zoom meeting dengan memanfaatkan media film komedi:

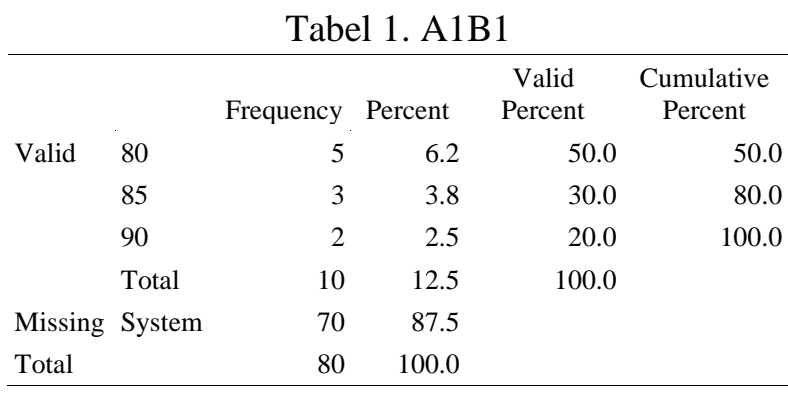




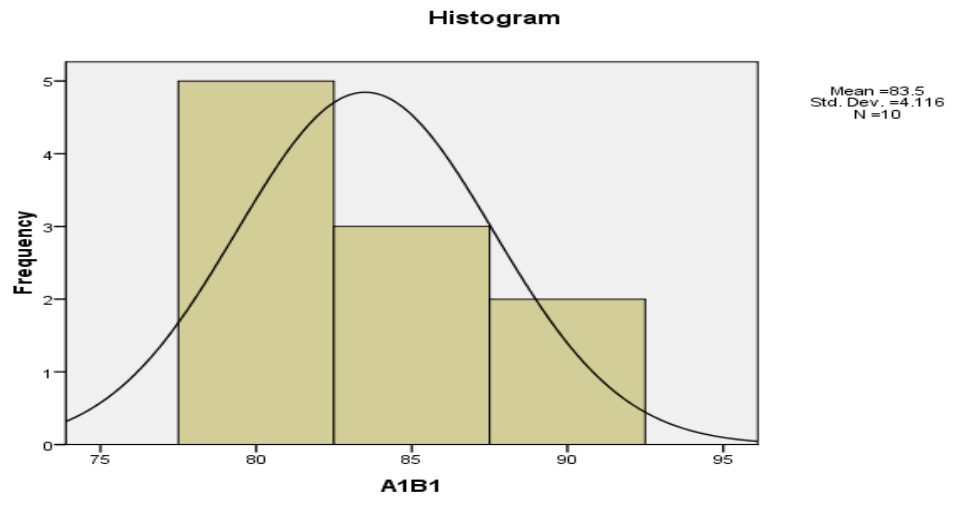

Gambar 1. Histogram A1B1

2. Deskripsi kemampuan menulis anekdot dengan perlakuan menggunakan aplikasi zoom meeting dengan memanfaatkan media konvensional (modul menulis) (A1B2).

Deskripsi kemampuan menulis anekdot dengan perlakuan menggunakan aplikasi zoom meeting dengan memanfaatkan media konvensional (modul menulis). Secara keseluruhan memiliki rentang 78 - 90 dengan skor terendah 78 dan skor tertinggi 90 dengan mempunyai nilai rata-rata 82, nilai median 81 nilai modus 80 , dan standar deviasi 3,860.

Berikut ini distribusi frekuensi dan histogram kemampuan menulis anekdot dengan perlakuan menggunakan aplikasi zoom meeting dengan memanfaatkan media konvensional (modul menulis):

Tabel. A1B2

\begin{tabular}{llrrrr}
\hline & & & & Valid & \multicolumn{2}{c}{$\begin{array}{c}\text { Cumulative } \\
\text { Percent }\end{array}$} \\
\hline Valid & 78 & 2 & 2.5 & 20.0 & 20.0 \\
& 80 & 3 & 3.8 & 30.0 & 50.0 \\
& 82 & 1 & 1.2 & 10.0 & 60.0 \\
& 85 & 3 & 3.8 & 30.0 & 90.0 \\
& 90 & 1 & 1.2 & 10.0 & 100.0 \\
& Total & 10 & 12.5 & 100.0 & \\
Missing & System & 70 & 87.5 & & \\
\multicolumn{2}{l}{ Total } & 80 & 100.0 & &
\end{tabular}

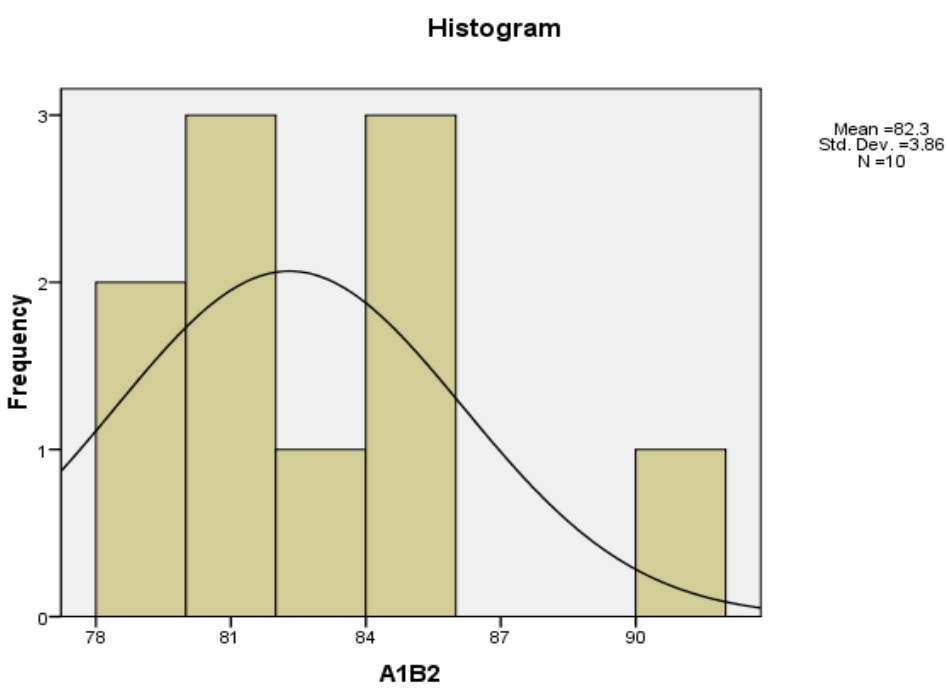

Gambar 2. Histogram A1B2 


\section{Deskripsi kemampuan menulis anekdot dengan perlakuan menggunakan google classroom} dengan memanfaatkan media film komedi (A2B1).

Deskripsi kemampuan menulis anekdot dengan perlakuan menggunakan google classroom dengan memanfaatkan media film komedi. Secara keseluruhan memiliki rentang 75 - 85 dengan skor terendah 75 dan skor tertinggi 85 dengan mempunyai nilai rata-rata 81 , nilai median 80 nilai modus 80 , dan standar deviasi 3,155.

Berikut ini distribusi frekuensi dan histogram kemampuan menulis anekdot dengan perlakuan menggunakan google classroom dengan memanfaatkan media film komedi.

\begin{tabular}{|c|c|c|c|c|c|}
\hline \multicolumn{6}{|c|}{ Tabel. A2B1 } \\
\hline & & Frequency & Percent & $\begin{array}{c}\text { Valid } \\
\text { Percent }\end{array}$ & $\begin{array}{l}\text { Cumulative } \\
\text { Percent }\end{array}$ \\
\hline \multirow[t]{5}{*}{ Valid } & 75 & 1 & 1.2 & 10.0 & 10.0 \\
\hline & 80 & 5 & 6.2 & 50.0 & 60.0 \\
\hline & 82 & 1 & 1.2 & 10.0 & 70.0 \\
\hline & 85 & 3 & 3.8 & 30.0 & 100.0 \\
\hline & Total & 10 & 12.5 & 100.0 & \\
\hline Missing & System & 70 & 87.5 & & \\
\hline Total & & 80 & 100.0 & & \\
\hline
\end{tabular}

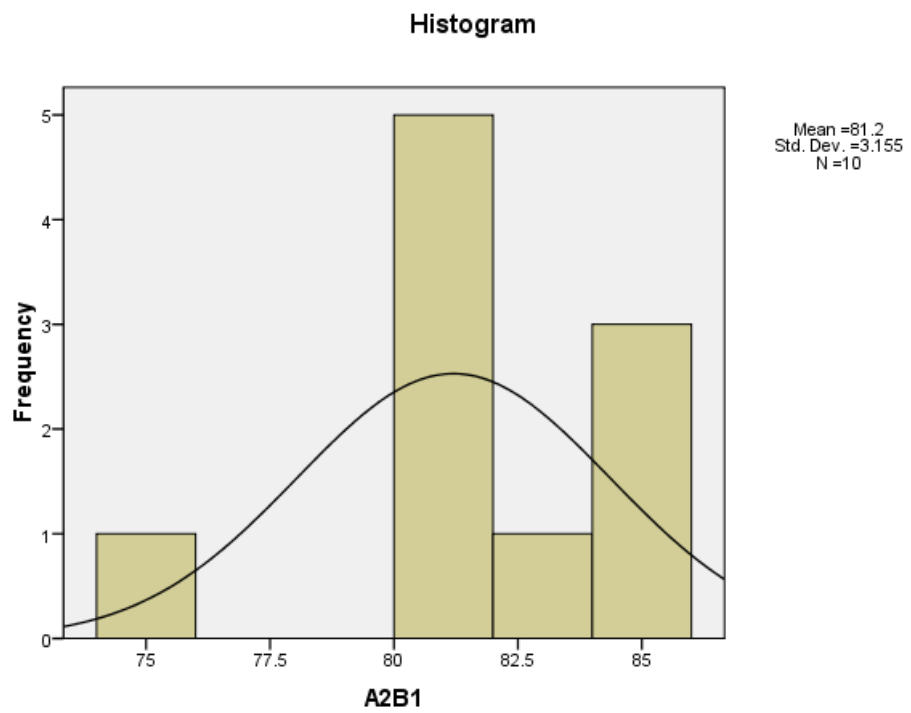

Gambar 3. Histogram A2B1

4. Deskripsi kemampuan menulis anekdot dengan perlakuan menggunakan google classroom dengan memanfaatkan media konvensional (modul menulis) (A2B2).

Deskripsi kemampuan menulis anekdot dengan perlakuan menggunakan google classroom dengan memanfaatkan media konvensional. Secara keseluruhan memiliki rentang $75-80$ dengan skor terendah 75 dan skor tertinggi 80 dengan mempunyai nilai rata-rata 77 , nilai median 76 nilai modus 75 , dan standar deviasi 2,497.

Berikut ini distribusi frekuensi dan histogram kemampuan menulis anekdot dengan perlakuan menggunakan google classroom dengan memanfaatkan media konvensional (modul menulis): 
Tabel. A2B2

\begin{tabular}{llrrrr}
\hline & & & & \multicolumn{2}{c}{$\begin{array}{c}\text { Cumulative } \\
\text { Percent }\end{array}$} \\
\hline Valid & 75 & 5 & 6.2 & 50.0 & 50.0 \\
& 78 & 1 & 1.2 & 10.0 & 60.0 \\
& 80 & 4 & 5.0 & 40.0 & 100.0 \\
& Total & 10 & 12.5 & 100.0 & \\
Missing & System & 70 & 87.5 & & \\
Total & & 80 & 100.0 & & \\
\hline
\end{tabular}

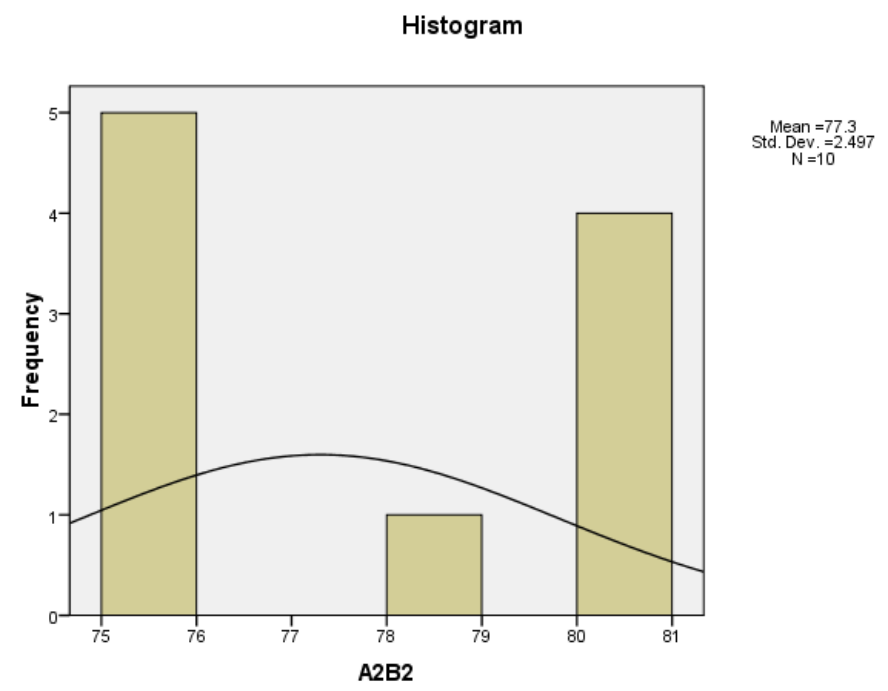

Gambar 4. Histogram A2B2

\section{Pengujian Pesyaratan Analisis}

Hasil perhitungan uji normalitas data menggunakan Kolmogorov_Smirnov pada taraf signifikan $\alpha=0,05$

Tabel. Tests of Normality

\begin{tabular}{lccccccc} 
& \multicolumn{3}{c}{ Kolmogorov-Smirnov ${ }^{\mathrm{a}}$} & \multicolumn{3}{c}{ Shapiro-Wilk } \\
& Statistic & df & Sig. & Statistic & df & Sig. \\
\hline $\begin{array}{l}\text { Unstandardized Residual } \\
\text { Kemampuan Menulis }\end{array}$ & 0.134 & 40 & 0.067 & 0.957 & 40 & 0.132 \\
\hline
\end{tabular}

\footnotetext{
a. Lilliefors Significance Correction
}

Berdasarkan dari uji normalitas diketahui nilai signifikansi 0,132 $\geq 0,19$ maka dapat disimpulkan bahwa maka nilai residual standard normal dengan program SPSS versi 16 for windows diperoleh nilai signifikansi $L o=0,132$ dengan $L_{\text {tabel }} 0,19$ dengan taraf signifikansi $\alpha=0,05$. Dengan demikian disimpulkan bawah kelompok dalam penelitian ini berasal dari populasi yang berdistribusi normal. Hal ini menunjukkan bahwa salah satu persyaratan uji $\mathrm{F}$ dalam penelitian ini telah terpenuhi.

Pengujian homogenitas pada kelompok ini menggunakan program versi 16 for windows dilakukan untuk menguji homogentias variabel hasil kemampuan menulis anekdot dengan data lebih dari dua kelompok. Hasil perhitungan uji homogenitas varians menggunakan uji Levene's dengan taraf signifikan $\alpha$ $=0,05$

Tabel. Levene's Test of Equality of Error Variances ${ }^{\mathrm{a}}$

Dependent Variable:Kemampuan Menulis Anekdot

\begin{tabular}{cccc}
\hline $\mathrm{F}$ & df1 & df2 & Sig. \\
\hline 1.217 & 3 & 36 & 0.317 \\
\hline
\end{tabular}


Ringkasan hasil perhitungan uji homogenitas menunjukkan bahwa $F_{0}=1,217$ dan Sig. 0,317. Hal ini berarti $\mathrm{F}_{\mathrm{o}} \leq \mathrm{F}_{\text {tabel }}=2$,86. Maka dapat disimpulkan bahwa data hasil kemampuan menulis anekdot mahasiswa memiliki varians populasi yang sama atau data berasal dari populasi yang homogen.

\section{Pengujian Hipotesis Penelitian}

Setelah dilakukan uji normalitas dan homogenitas dan hasil menunjukkan bahwa sampel penelitian berasal dari populasi berdistribusi normal dan varian sampel homogen, maka pengujian hipotesis dapat dilakukan. Pengujian hipotesis penelitian ini dilakukan dengan teknik analisis ANAVA dua jalan dilakukan perhitungan jika kemudian data ditemukan adanya interaksi maka dilanjutkan dengan uji Tukey.

Adapun deskripsi statistik dan ringkasan hasil analisis data dengan menggunakan ANAVA dapat dilihat pada tabel berikut ini:

Tabel. Ringkasan Pengujian Hipotesis Penelitian Hasil Analisis ANAVA

Tests of Between-Subjects Effects

\begin{tabular}{|c|c|c|c|c|c|}
\hline Source & Type III Sum of Squares & $\mathrm{df}$ & Mean Square & $\mathrm{F}$ & Sig. \\
\hline Corrected Model & $216.475^{\mathrm{a}}$ & 3 & 72.158 & 6.009 & .002 \\
\hline Intercept & 262926.225 & 1 & 262926.225 & $2.190 \mathrm{E} 4$ & .000 \\
\hline Aplikasi_Pembelajaran & 65.025 & 1 & 65.025 & 5.415 & .026 \\
\hline Media_Pembelajaran & 133.225 & 1 & 133.225 & 11.094 & .002 \\
\hline $\begin{array}{l}\text { Aplikasi_Pembelajaran * } \\
\text { Media_Pembelajaran }\end{array}$ & 18.225 & 1 & 18.225 & 1.518 & .226 \\
\hline Error & 432.300 & 36 & 12.008 & & \\
\hline Total & 263575.000 & 40 & & & \\
\hline Corrected Total & 648.775 & 39 & & & \\
\hline
\end{tabular}

a. R Squared $=.334$ (Adjusted R Squared $=.278$ )

Berdasarkan data pada tabel di atas, maka hipotesis penelitian yang dilakukan dapat terjawab. Adapun penjelasan mengenai pembahasannya untuk masing-masing hipotesis adalah sebagai berikut:

1. Pengaruh aplikasi zoom meeting terhadap kemampuan menulis anekdot

Dari hasil pengujian dengan program SPSS versi 16 for windows yang ditunjukkan dalam tabel ringkasan pengujian hipotesis penelitian hasil analisis ANAVA di atas (Tests of Between-Subjects Effects) terlihat bahwa $\mathrm{F}_{0}=5,415$ dan sig. $=0,026 \leq 0,05$. Dengan demikian hipotesis nol $\left(\mathrm{H}_{0}\right)$ ditolak dan hipotesis alternatif $\left(\mathrm{H}_{1}\right)$ diterima. Hal ini membuktikan bahwa rerata (mean) kemampuan menulis anekdot mahasiswa yang diberi perlakuan menggunakan aplikasi zoom meeting dengan mahasiswa yang diberi perlakuan menggunakan google classroom adalah terdapat perbedaan yang signifikan. Dan rata-rata kemampuan menulis anekdot dengan menggunakan aplikasi zoom meeting lebih besar dari pada rata-rata kemampuan menulis anekdot dengan menggunakan google classroom.

2. Pengaruh media film komedi terhadap kemampuan menulis anekdot

Dari hasil pengujian dengan program SPSS versi 16 for windows yang ditunjukkan dalam tabel ringkasan pengujian hipotesis penelitian hasil analisis ANAVA di atas (Tests of Between-Subjects Effects) terlihat bahwa $\mathrm{F}_{0}=11.094$ dan sig. $=0,02 \leq 0,05$. Dengan demikian hipotesis nol $\left(\mathrm{H}_{0}\right)$ ditolak dan hipotesis alternatif $\left(\mathrm{H}_{1}\right)$ diterima. Hal ini membuktikan bahwa rerata (mean) kemampuan menulis anekdot mahasiswa yang diberi perlakuan menggunakan media film komedi dengan mahasiswa yang diberi perlakuan menggunakan media konvensional (modul menulis) adalah terdapat perbedaan yang signifikan. Dan rata-rata kemampuan menulis anekdot mahasiswa yang diberi perlakuan menggunakan media film komedi lebih besar dari pada rata-rata kemampuan menulis anekdot yang diberi perlakuan menggunakan media konvensional (modul menulis).

3. Pengaruh interaksi aplikasi zoom meeting dan media film komedi secara bersama-sama terhadap kemampuan menulis anekdot

Dari hasil pengujian dengan program SPSS versi 16 for windows yang ditunjukkan dalam tabel ringkasan pengujian hipotesis penelitian hasil analisis ANAVA di atas (Tests of Between-Subjects Effects) terlihat bahwa $\mathrm{F}_{0}=1.518$ dan sig. $=0,226 \geq 0,05$. Dengan demikian hipotesis nol $\left(\mathrm{H}_{0}\right)$ diterima dan hipotesis alternatif $\left(\mathrm{H}_{1}\right)$ ditolak. Hal ini membuktikan bahwa tidak terdapat pengaruh yang signifikan aplikasi zoom meeting dan media film komedi terhadap kemampuan menulis anekdot 
mahasiswa. Karena tidak ada interaksi antara variabel bebas yaitu aplikasi zoom meeting dengan media film komedi terhadap kemampuan menulis anekdot, maka analisis data kemampuan menulis anekdot tidak perlu diteruskan lebih lanjut.

\section{Simpulan}

berdasarkan data yang diperoleh hasil pengujian hipotesis pembahasan hasil penelitian, maka dapat dirumuskan simpulan sebagai berikut:

1. Terdapat pengaruh yang signifikan aplikasi zoom meeting terhadap kemampuan menulis anekdot. Dari hasil penelitian dengan menggunakan analisis varians dua jalur dengan taraf signifikan 0,05 di peroleh $\mathrm{F}_{0}=1.518$ dan sig. $=0,226 \geq 0,05$. Hal ini menjelaskan bahwa mahasiswa yang diberi perlakuan menggunakan aplikasi zoom meeting mampu meningkatkan kemampuan menulis anekdot dengan baik dibandingkan dengan kemampuan menulis anekdot mahasiswa yang diberi perlakuan menggunakan google classroom.

2. Terdapat pengaruh yang signifikan media film komedi terhadap kemampuan menulis anekdot. Dari hasil penelitian dengan menggunakan analisis varians dua jalur dengan taraf signifikan 0,05 di peroleh $\mathrm{F}_{0}=11.094$ dan sig. $=0,02 \leq 0,05$. Hal ini menjelaskan bahwa mahasiswa yang diberi perlakuan menggunakan media film komedi mampu meningkatkan kemampuan menulis anekdot dengan baik dibandingkan dengan kemampuan menulis anekdot mahasiswa yang diberi perlakuan menggunakan media konvensional (modul menulis).

3. Tidak terdapat pengaruh yang signifikan interaksi aplikasi zoom meeting dan media film komedi terhadap kemampuan menulis anekdot. Dari hasil penelitian dengan menggunakan varians dua jalur dengan taraf signifikan 0,05 diperoleh $\mathrm{F}_{0}=1.518$ dan sig. $=0,226 \geq 0,05$. Hal ini berarti bahwa masingmasing variabel sama-sama memiliki pengaruh yang baik terhadap kualitas kemampuan menulis anekdot, atau dapat dilakukan bersama-sama. Berdasarkan hasil penelitian ini dapat disimpulkan bahwa salah satu variabel bebas yaitu aplikasi zoom meeting atau media film komedi yang digunakan dalam proses pembelajaran sudah mampu mempengaruhi kemampuan menulis anekdot menjadi lebih baik.

\section{Ucapan Terima Kasih}

Pada kesempatan ini kami mengucapkan terima kasih kepada semua pihak yang telah memberikan bantuan dan dorongan dalam melaksanakan penelitian ini, kepada Universitas Indraprasta PGRI, seluruh staf civitas academica, baik dosen maupun mahasiswa yang terlibat dalam mata kuliah menulis.

\section{Daftar Rujukan}

Afifuloh. "Film Komedi Sebagai Media Dakwah (Analisis Film "Insya Allah Sah". [Skripsi] Universitas Islam Negeri Walisongo Semarang. (2019).

Asrori, F. fajar. Pemanfaatan Google Classroom dalam Pembelajaran Menulis Puisi Masa Pandemik Covid 19. Jurnal Bahasa, Sastra, dan Pengajarana (2021), 10: 169-172.

Aurora, A. Pengaruh Penggunaan Media Pembelajaran E-learning terhadap Motivasi Belajar Mahasiswa di Universitas Negeri Padang. JTEV (Jurnal Teknik Elektro Dan Vokasional) (2019), 5, 11-16.

Bunyamin, A. Penerapan Metode Belajar Diskusi Berbantuan Google Classroom untuk Meningkatkan Hasil Belajar Gambar Teknik Mesin Siswa Kelas X Teknik Pengelasan SMK Negeri 1 Kecamatan Guguak. Ranah Research (2019), 2, 213-219.

Defrizal, D, dkk. "Analisis Laporan Keuangan Untuk Mengukur Kinerja Keruangan (Studi Kasus Pada PT Kalbe Farma)". Jurnal Manajemen Dan Bisnis, 11(1). (2020).

Dewi, dkk. "BLENDED LEARNING Konsep dan Implementasi pada Pendidikan Tinggi Vokasi". (2019) Haryanti, Ade Siti. "Pengaruh Media Pembelajaran dan Motivasi Belajar Terhadap Kemampuan Menulis Deskripsi Siswa Kelas X Sekolah Menengah Atas Swasta Di Kecamatan Balaraja". Jurnal Lentera, 1 (2016): 32-55.

Haryanti, Ade Siti. "Penggunaan Media Gambar dan Media Radio Pada Pembelajaran Menulis Deskripsi Siswa Kelas X SMA Tunas Harapan Balaraja-Tangerang". Jurnal Kredo, 1(2018), 14-25. 
Haqien, Danin, D. R. Pemanfaatan Zoom Meeting untuk Proses Pembelajaran Pada Masa Pandemik Covid19. SAP (Susunan Artikel Pendidikan) (2020), 5, 51-56.

Irmada, F. Keefektifan Pembelajaran Online Melalui Zoom Meeting di Masa Pandemi bagi Mahasiswa. Jurnal Basicedu (2021), 5, 2424-2429.

Miftah, M. "Peran Dan Fungsi Media Pembelajaran Sebagai Upaya Peningkatan Kemampuan Belajar Siswa". Jurnal KWANGSAN, 1(9) (2013), 1689-1699.

Mulatsih, B. Penerapan Aplikasi Google Classroom, Google Form, dan Quizizz dalam Pembelajaran Kimia di Masa Pandemik Covid-19. Ideguru : Jurnal Karya Ilmiah Guru (2020), 5, 16-26.

Rahman, Fauzi. Song Lyrics As A Stimulan Media In Writing Short Stories For Junior High School Students. Hortatori, 4. (2020): 109-11.

Ramli. Media Teknlogi Pembelajaran. 1-3. (2012).

Rifai, Badiyah. "Bahasa dan Sastra Indonesia". Kementerian Pendidikan dan Kebudayaan. (2019).

Septiani, D. (2017). Influence of larning interest and vocabulary on the writing description of secondary school in Depok. Hortatori, 1. (2017): 168-178.

Sugiyono. Metode Penelitian Kuantitatif, Kualitatif, dan R\&D. Alfabetha. (2013).

Sukiman. "Pengembangan Media Pembelajaran".PT Pustaka Insan Madani, Anggota IKAPI. (2012)

Yunita. "Pembelajaran Jarak Jauh dengan Media E-Learning: Dikursus Melalui Problem Soving Di Era Pandemik Covid-19". Jurnal Edukasi Nonformal (2021), 1: 134-146. 